\title{
Prevention of bone mineral density loss in patients with rheumatoid arthritis treated with anti-TNF $\alpha$ therapy
}

\author{
Hubert Marotte \\ Pierre Miossec \\ Clinical Immunology Unit, \\ Departments of Immunology \\ and Rheumatology, University \\ of Lyon, and Unité Mixte Hospices \\ Civils de Lyon-bioMérieux, Hôpital \\ Edouard Hérriot, Lyon, France
}

\begin{abstract}
This review focuses on recent advances in the effect of anti-TNF $\alpha$ therapy on bone metabolism and bone mineral density (BMD) in rheumatoid arthritis (RA). RA is a chronic disease characterized by inflammation of the synovial joint, cartilage degradation, and subsequent bone destruction. Bone damage is often manifested as erosions, localized juxta-articular bone loss, or generalized bone loss. Thus, blockade of TNFa not only serves to block inflammation, but also halts the erosive nature of RA and generalized/localized juxta-articular bone loss. Here, we review recent findings showing that anti-TNFa therapy is also effective on halting systemic bone loss. In vitro, TNFa reduces osteoblast activity and increases osteoclast activity through RANKL-RANK pathway. In arthritis animal models, an imbalance between bone formation and resorption is observed. In humans, this coupling of destruction is restored by anti-TNF $\alpha$ therapy early on, but only for a few months. Thus, anti-TNF $\alpha$ prevents the BMD loss in RA patients. In summary, TNFa blockade is not only able to prevent joint destruction, but it is also able to prevent bone loss in RA patients. Future studies are needed to address if TNFa blockers have an effect on bone fractures.
\end{abstract}

Keywords: rheumatoid arthritis, TNF $\alpha$, bone mineral density, infliximab

\section{Introduction}

Rheumatoid arthritis (RA) is a chronic disease characterized by inflammation of the synovial joint, cartilage degradation, and subsequent bone destruction. Bone damage often is manifested as erosions, localized juxta-articular bone loss, or generalized bone loss (Kroot et al 2001; Gough et al 1994). The later is likely attributed to a number of factors including disease itself, reduced exercise activity, steroids therapy (Laan et al 1993; Hall et al 1993; Cortet et al 1997; Haugeberg et al 2002; Mikuls 2003), or common postmenopausal osteoporosis. Accelerated generalized bone loss is often considered as one of the major complications of RA (Westhovens and Dequeker 2000; Green and Deodhar 2001; Sambrook et al 1987; Goldring and Gravallese 2000), as patients often have an increased risk of hip (Cooper et al 1995; Huusko et al 2001; van Staa et al 2006) or vertebral fractures (Spector et al 1993; Peel et al 1995; van Staa et al 2006). Blockade of mediators of joint inflammation is a promising strategy to halt or perhaps improve the severity of these bone related manifestations.

\section{TNF $\alpha$ a key cytokine target}

For almost a decade, anti-TNF $\alpha$ therapy has established a new standard in RA therapy, creating new objectives for disease remission on both the clinical and radiological level. Currently, three anti-TNF $\alpha$ drugs are commercially available and have been successfully used in halting both joint inflammation and destruction in RA patients (Charles et al 1999; Maini et al 1999; Weinblatt et al 1999; Genovese et al 2002; 
Lipsky et al 2000; Keystone et al 2004; Smolen et al 2005). Furthermore TNF $\alpha$ plays a central role not only in RA, but also in common osteoporosis. In fact, TNF $\alpha$ has been shown to increase bone resorption in systemic osteoporosis related to oestrogen deficiency (Pacifici and Avioli 1993). In addition, transgenic mice expressing soluble $\mathrm{TNF} \alpha$ receptor to neutralize TNF $\alpha$, were protected from oestrogen deficiencyrelated bone loss (Ammann et al 1997). Thus, blockade of TNF $\alpha$ not only serves to block inflammation, but also halts the erosive nature of RA and generalized/localized juxta-articular bone loss. Here, we review recent findings showing that anti-TNF $\alpha$ therapy is also effective on halting systemic bone loss.

\section{In vitro effects of TNF $\alpha$ on osteoblasts and osteoclasts (Figure I)}

Over the last two decades, there have been a number of findings on the effects of TNF $\alpha$ on osteoblast activity. These include the different down regulatory effects of TNF $\alpha$ on osteoblasts: differentiation, mineralization, and expression of the skeletal bone matrix (Bertolini et al 1986; Nguyen et al 1991; Taichman and Hauschka 1992; Kuroki et al 1994; Nakase et al 1997; Gilbert et al 2000, 2002). Furthermore,
TNF $\alpha$ stimulation also induces apoptosis in osteoblasts (Hill et al 1997; Jilka et al 1998).

Research on the development of bone erosions has rapidly increased over recent years. First was the detection of osteoclasts at sites of arthritic bone erosion (Ishikawa et al 1984). Second was the discovery of the balance between TNF superfamily molecules: osteoprotegerin (OPG), receptor activator of nuclear factor $\kappa B$ ligand (RANKL), receptor activator of nuclear factor $\kappa \mathrm{B}$ (RANK), and TNF-related apoptosis inducing ligand (Gravallese et al 2000; Kong et al 1999, 2000; Hofbauer and Heufelder 2001). RANKL is a transmembrane receptor protein and its inhibition by osteoprotogerin (OPG), a decoy receptor, has important implications for inflammation research as well as for bone physiology (Kong et al 1999; Emery et al 1998).

Osteoblasts express RANKL constitutively on their cell surface. RANKL interacts with its cognate receptor RANK, which is expressed on osteoclast precursors and promotes osteoclast differentiation. Interaction of RANKL with RANK on mature osteoclasts results in their activation and prolonged survival. Importantly, osteoclasts are clearly the principal instruments of this destruction. As shown by studies using osteoclast deficient animal models of disease, treatment with antiresorptive agents such as OPG, delays bone damage in vivo (Joosten et al 1999; Kong et al 1999;

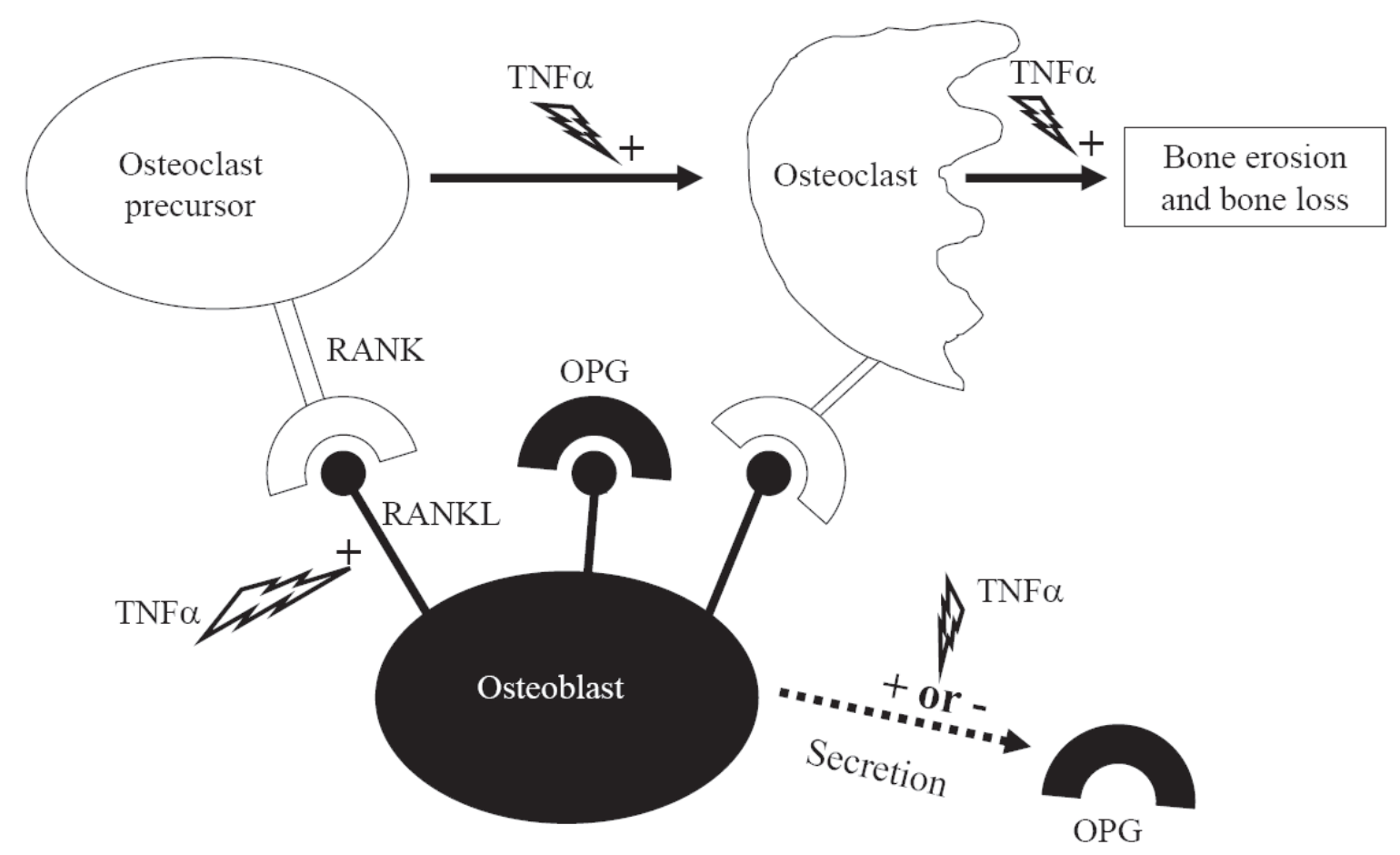

Figure I Increasing the balance of receptor activator of nuclear factor $\kappa B$ ligand (RANKL)-receptor activator of nuclear factor $\kappa B$ (RANK) induced by tumor necrosis factor alpha $(\mathrm{TNF} \alpha)$.

Abbreviations: OPG, osteoprotegerin; +, stimulation;-, inhibition. 
Pettit et al 2001; Gravallese 2002; Redlich et al 2002b; Saidenberg-Kermanac'h et al 2004).

RANKL also plays a key role in the regulation of osteoclastogenesis, osteoclast activation, dendritic cell survival, lymphocyte development, and lymph node organogenesis (Kong et al 1999). Studies showing that the RANKL/RANK ratio regulates osteoclastogenesis have profoundly influenced our current understanding of inflammation mediated bone loss (Kong et al 1999; Gravallese et al 1998, 2000; Shigeyama et al 2000; Takayanagi et al 2000; Redlich et al 2002a; Romas et al 2002; Pettit et al 2001). OPG deficient mice exhibit massive osteoporosis and also develop calcified lesions in the aorta and renal arteries (Bucay et al 1998; Min et al 2000). In contrast, the overexpression of OPG in transgenic mice results in severe osteopetrosis and splenomegaly (Min et al 2000). The inhibition of bone resorption by the administration of OPG has been demonstrated in postmenopausal women (Bekker et al 2001) and in mice challenged with interleukin-1 $\beta$ (IL-1 $\beta$ ) or TNF $\alpha$ (Morony et al 1999). Treatment with anti-RANKL antibody has also resulted in an increased amount of bone mineral density (BMD) (McClung et al 2006).

TNF $\alpha$ elevates RANKL expression in numerous cell types: stroma cells, synoviocytes, osteoblasts, endothelial cells, human microvascular endothelial cells, $\mathrm{T}$ cells, and B cells (Hofbauer et al 1998; Cenci et al 2000; Kanematsu et al 2000 Nakashima et al 2000; Page and Miossec 2005; Collin-Osdoby et al 2001). TNF $\alpha$ also has differential effects on OPG expression depending on cell type: a decrease is observed in osteoblasts/stromal cells (Nakashima et al 2000), while an increase is observed in endothelial cells (CollinOsdoby et al 2001), osteoblast cells (Hofbauer et al 1998), and in RA synoviocytes (Marotte et al 2005). In this later, an inhibition of this stimulation is observed when infliximab is added (Marotte et al 2005).

RA and psoriatic arthritis have a marked increase in the number of pre-osteoclasts in their peripheral blood mononuclear cell populations compared to normal and osteoarthritis controls (Ritchlin et al 2003). Importantly, this increase also appears to be reversible with anti-TNF $\alpha$ therapy, and may be a predominant mechanism by which this treatment inhibits erosions in these patients.

\section{Unbalance between bone formation and resorption in arthritis model}

Much less is known about bone formation in animal models of immune-mediated arthritis. Given the insidious erosive course of these conditions, it is obvious that bone resorption outweighs bone formation. However, bone formation is strongly down-regulated during chronic arthritis. For example, studies in animal models, which addressed systemic bone changes, showed reduction in bone formation in femurs by histomorphometry as well as low serum levels of the bone formation marker, osteocalcin (OC) (Bonnet et al 1993; Hoshino et al 2001). Furthermore, blocking TNF $\alpha$ prevents bone loss in animal models and increases trabecular thickness (Joosten et al 1999; Saidenberg-Kermanac'h et al 2004).

\section{Effect of anti-TNF $\alpha$ on bone markers}

As shown above, bone remodeling is the result of two opposing activities, the production of new bone matrix by osteoblasts and the destruction of old bone by osteoclasts. Biochemical markers of bone turnover are substances in the blood or urine that are produced or released during bone remodeling. They provide semi-quantitative information on bone remodeling. At present, the most specific markers for bone formation are serum OC, bone-specific alkaline phosphate (BAP), and procollagen type I N-terminal propeptide (PINP). OC is down regulated by steroid therapy (Vergely et al 2002), whereas BAP and PINP changes are not linked to this therapy (Cortet et al 2001). For the evaluation of bone resorption, numerous serum markers of type I collagen telopeptide epitopes (CTX-I, NTX-I, and ICTP) and deoxypyridinoline are currently used. Among them, C-telopeptides (CTX-I and ICTP) are the most sensitive markers of bone resorption (Garnero and Delmas 2004). By two different enzymatic pathways, two C-telopeptide fragments are released from bone type I collagen (Sassi et al 2000; Garnero et al 2003). ICTP is generated by matrix metalloproteases whose activity plays an important role in collagen degradation associated with RA (Brennan et al 1997). In contrast, CTX-I is generated by cathepsin K, which is the key osteoclastic enzyme for systemic bone resorption (Inui et al 1997).

Several cross-sectional studies in human RA support these experimental findings. RA patients have significantly lower osteocalcin levels than healthy controls (Al-Awadhi et al 1999; Garnero et al 1999; Seriolo et al 2002). Indeed, in one of our previous studies (Garnero et al 1999), uncoupling between bone destruction and formation was observed in destructive RA, whereas such uncoupling was not observed in benign non-destructive RA. It now appears that TNF $\alpha$ inhibition may restore this coupling of destruction with formation. Initial clinical studies on the effect of TNF $\alpha$ blockers on bone focused primarily on bone markers. Bone formation markers 
Table I Effect of TNF $\alpha$ and anti-TNF $\alpha$ on bone cells, bone biomarkers, X-rays, and bone mineral density

\begin{tabular}{|c|c|c|c|}
\hline & & TNF $\alpha$ & Anti-TNF $\alpha$ \\
\hline \multirow[t]{2}{*}{ In vitro } & Osteoblasts & $\begin{array}{l}\text { Inhibition of differentiation (Gilbert et al 2000; Gilbert et al } \\
\text { 2002) } \\
\text { Inhibition of mineralization (Taichman and Hauschka; 1992; } \\
\text { Kuroki et al I994; Nakase et al I997) } \\
\text { Skeletal bone matrix synthesis:inhibition (Taichman and } \\
\text { Hauschka I992; Kuroki et al I994; Nakase et al I997; Yudoh et al } \\
\text { 2000) } \\
\text { Induction of apoptosis (Hill et al 1997; } \\
\text { Jilka et al I998) } \\
\text { Stimulation of RANKL expression (Nakashima et al 2000; } \\
\text { Hofbauer et al 1998) }\end{array}$ & $?$ \\
\hline & Osteoclasts & $\begin{array}{l}\text { Activation via RANK/RANKL } \\
\text { Increasing of OPG production (Collin-Osdoby et al 200I; } \\
\text { Hofbauer et al I998; Marotte et al 2005) } \\
\text { Decreasing of OPG production (Nakashima et al 2000) }\end{array}$ & $\begin{array}{l}? \\
\text { Decrease of OPG production } \\
\text { (Marotte et al 2005) }\end{array}$ \\
\hline \multirow[t]{3}{*}{ In vivo } & $\begin{array}{l}\text { Biomarkers } \\
\text { of bone } \\
\text { remodeling }\end{array}$ & $\begin{array}{l}\text { Decreasing of biomarkers of bone formation (Bonnet et al 1993) } \\
\text { Increasing of biomarkers of bone resorption (Saidenberg- } \\
\text { Kermanac'H et al 2004; Joosten et al 1999) }\end{array}$ & $\begin{array}{l}\text { Early restoration of the balance between } \\
\text { biomarkers of bone formation and resorp- } \\
\text { tion (Lange et al } 2005 \text {; Vis et al } 2005 \text {; Vis et al } \\
2006 \text {; Chopin et al 2007) }\end{array}$ \\
\hline & X-rays & Erosion progression & $\begin{array}{l}\text { No erosion progression (Smolen et al 2005; } \\
\text { Genovese et al 2002; Keystone et al 2004; } \\
\text { Lipsky et al 2000) }\end{array}$ \\
\hline & $\begin{array}{l}\text { Bone } \\
\text { mineral } \\
\text { density }\end{array}$ & Bone loss & Prevention of bone loss (Marotte et al 2007) \\
\hline
\end{tabular}

Abbreviations: TNF $\alpha$, tumor necrosis factor alpha; RANKL, receptor activator of nuclear factor $\kappa B$ ligand; RANK, receptor activator of nuclear factor $\kappa B$; OPG, osteoprotegerin.

(OC and PINP) showed an early increase at 2 and 6 weeks after initiation of infliximab treatment in a study conducted in 68 RA patients (Vis et al 2003), whereas only ICTP was down regulated at 6 weeks despite having negligible effects on CTX-I. The long-term effect of infliximab at 1 year was described in a small population of 26 patients with RA (Lange et al 2005), with a persistent increase in OC and a persistent decrease in CTX-I. However, in another study of 70 patients with RA treated with infliximab plus methotrexate, a decrease was observed only in bone resorption markers (urinary excretion of NTX-I and deoxypyridinoline), whereas BAP did not increase (Torikai et al 2006). The same pattern with a rapid decrease of CTX-I levels followed by a return to baseline levels at 1 year was observed in several studies in RA (Lange et al 2005; Vis et al 2005, 2006; Chopin et al 2007), and also in spondylarthropathy (Briot et al 2005). Only one study explored the changes of CTX-I and ICTP under infliximab over one year (Chopin et al 2007). ICTP level showed a later decrease compared to CTX-I, suggesting different specific resorption processes. In another study, infliximab therapy had a less significant effect on serum
OPG and sRANKL levels in RA patients (Ziolkowska et al 2002). Recently, decreases in CTX-I and sRANKL on serum were observed over 1 year of infliximab treatment (Vis et al 2006). In summary, early changes in bone remodeling under infliximab was characterized by an uncoupled response with TNF $\alpha$ inhibition inducing a decrease in bone resorption. This was followed by a secondary steady-state with higher resorption level to match bone formation. Finally, the ratio between markers of bone formation and bone resorption appeared to be increased.

\section{Effect of anti-TNF $\alpha$ on BMD}

Bone mineral density (BMD) can be assessed by numerous methods, but dual $x$ ray absorptiometry (DXA) is considered the "gold standard" (Genant et al 1996). In practice, lumbar spine (L1-4) and total hip are measured after a daily calibration using an external phantom to detect a machine drift. For longitudinal studies, several assessments need to be performed in the same bone densitometer.

High BMD loss in RA patients was associated with joint damage progression, disease activity, functional disability 
and immobility in previous longitudinal studies, even in early RA (Gough et al 1994; Shenstone et al 1994; Cortet et al 2000; Forslind et al 2003; Jensen et al 2004). However, several observational studies were performed without enrolled control groups. The first studies enrolled a small number of patients, and showed an increase of BMD in numerous inflammatory disorders. In patients with RA $(n=26)$ (Lange et al 2005), with spondylarthropathy $(n=29)$ (Allali et al 2003) and with Crohn's disease $(n=46)$ (Bernstein et al 2005), a significant increase of BMD values was observed. Another study enrolled 102 RA patients in an open prospective cohort. After 1 year of infliximab therapy, no bone loss was observed in the spine and hip, while a decrease of BMD was observed at the hands (Vis et al 2006). Unfortunately, no control group was used in the study.

The lack of a control group is a major limitation for predicting a true estimation of the effect of anti-TNF $\alpha$ treatment on bone. The gold standard for this type of study would be a double blind randomized vs placebo trial. However, since TNF $\alpha$ blockers are now on the market, ethical issues would prevent such a randomized vs placebo trial. In order to have a control population for such a study, we used another option. We performed a historical control study, composed of active RA patients followed before the time of TNF $\alpha$ blockers and treated with methotrexate alone (Marotte et al 2007). This historical control group is of critical interest because it was not influenced by the use of TNF $\alpha$ inhibitors. In the control group $(\mathrm{n}=99)$, we found a significant decrease of BMD $(-3.4 \%$ at the femoral neck and $-3.9 \%$ at lumbar spine, $\mathrm{p}<0.001$ ), while no decrease was observed in the group treated by methotrexate and infliximab. Similar results were observed when putative cofactors are considered (sex status, age, menopause status, steroids or biphosphonate therapy, and RA activity). Furthermore, there was no significant difference in BMD changes between responders and non responders. For the non responders, the change in lumbar spine BMD was $+0.4 \%$ vs $-0.8 \%$ for the responders. Same trend was observed in femoral neck with BMD change at $+2.0 \%$ in the non-responders vs $-0.4 \%$ in the responders. This protective effect observed in clinical non responders to infliximab is in accordance with the findings of a recent study (Lipsky et al 2000; Genovese et al 2002; Keystone et al 2004; Smolen et al 2005) that demonstrated protective effects on joint destruction in the absence of clinical response.

Since our study, new data is available coming from the BeSt study, which is a multicenter, randomized clinical trial designed to compare the effectiveness of four different treatment strategies in patients with recently diagnosed, active
RA (Guler-Yuksel et al 2008). The main finding of this study was that there were no differences between the treatment groups. Again in this study, no appropriate control group was used according to ethical issues. Furthermore, the lack of bone loss in the group with steroids can be explained in part by the large prescription of biphosphonate therapy in this subgroup.

\section{Conclusion}

In summary, TNF $\alpha$ blockade is not only able to prevent joint destruction, but it is also able to prevent bone loss in RA patients. Future studies are needed to address if TNF $\alpha$ blockers have an effect on bone fractures.

\section{Disclosures}

Neither author has any conflicts of interest to disclose.

\section{References}

Al-Awadhi A, Olusi S, Al-Zaid N, et al. 1999. Serum concentrations of interleukin 6, osteocalcin, intact parathyroid hormone, and markers of bone resorption in patients with rheumatoid arthritis. $J$ Rheumatol, 26:1250-6.

Allali F, Breban M, Porcher R, et al. 2003. Increase in bone mineral density of patients with spondyloarthropathy treated with anti-tumour necrosis factor alpha. Ann Rheum Dis, 62:347-9.

Ammann P, Rizzoli R, Bonjour JP, et al. 1997. Transgenic mice expressing soluble tumor necrosis factor-receptor are protected against bone loss caused by estrogen deficiency. J Clin Invest, 99:1699-703.

Bekker PJ, Holloway D, Nakanishi A, et al. 2001. The effect of a single dose of osteoprotegerin in postmenopausal women. J Bone Miner Res, $16: 348-60$.

Bernstein M, Irwin S, Greenberg GR. 2005. Maintenance infliximab treatment is associated with improved bone mineral density in Crohn's disease. Am J Gastroenterol, 100:2031-5.

Bertolini DR, Nedwin GE, Bringman TS, et al. 1986. Stimulation of bone resorption and inhibition of bone formation in vitro by human tumour necrosis factors. Nature, 319:516-8.

Bonnet J, Zerath E, Picaud N, et al. 1993. Bone morphometric changes in adjuvant-induced polyarthritic osteopenia in rats:evidence for an early bone formation defect. J Bone Miner Res, 8:659-68.

Brennan FM, Browne KA, Green PA, et al. 1997. Reduction of serum matrix metalloproteinase 1 and matrix metalloproteinase 3 in rheumatoid arthritis patients following anti-tumour necrosis factor-alpha (cA2) therapy. BrJ Rheumatol, 36:643-50.

Briot K, Garnero P, Le Henanff A, et al. 2005. Body weight, body composition, and bone turnover changes in patients with spondyloarthropathy receiving anti-tumour necrosis factor $\{$ alpha\} treatment. Ann Rheum Dis, 64:1137-40.

Bucay N, Sarosi I, Dunstan CR, et al. 1998. osteoprotegerin-deficient mice develop early onset osteoporosis and arterial calcification. Genes Dev, 12:1260-8.

Cenci S, Weitzmann MN, Roggia C, et al. 2000. Estrogen deficiency induces bone loss by enhancing T-cell production of TNF-alpha. J Clin Invest, 106:1229-37.

Charles P, Elliott MJ, Davis D, et al. 1999. Regulation of cytokines, cytokine inhibitors, and acute-phase proteins following anti-TNF-alpha therapy in rheumatoid arthritis. J Immunol, 163:1521-8.

Chopin F, Garnero P, Le Henanff A, et al. 2007. Long term effects of Infliximab on bone and cartilage turnover markers in patients with rheumatoid arthritis. Ann Rheum Dis. 
Collin-Osdoby P, Rothe L, Anderson F, et al. 2001. Receptor activator of NF-kappa B and osteoprotegerin expression by human microvascular endothelial cells, regulation by inflammatory cytokines, and role in human osteoclastogenesis. J Biol Chem, 276:20659-72.

Cooper C, Coupland C, Mitchell M. 1995. Rheumatoid arthritis, corticosteroid therapy and hip fracture. Ann Rheum Dis, 54:49-52.

Cortet B, Cortet C, Blanckaert F, et al. 2001. Quantitative ultrasound of bone and markers of bone turnover in Cushing's syndrome. Osteoporos Int, 12:117-23.

Cortet B, Flipo RM, Pigny P, et al. 1997. How useful are bone turnover markers in rheumatoid arthritis? Influence of disease activity and corticosteroid therapy. Rev Rhum Engl Ed, 64:153-9.

Cortet B, Guyot MH, Solau E, et al. 2000. Factors influencing bone loss in rheumatoid arthritis:a longitudinal study. Clin Exp Rheumatol, 18:683-90.

Emery JG, McDonnell P, Burke MB, et al. 1998. Osteoprotegerin is a receptor for the cytotoxic ligand TRAIL. J Biol Chem, 273:14363-7.

Forslind K, Keller C, Svensson B, et al. 2003. Reduced bone mineral density in early rheumatoid arthritis is associated with radiological joint damage at baseline and after 2 years in women. $J$ Rheumatol, 30:2590-6.

Garnero P, Delmas PD. 2004. Noninvasive techniques for assessing skeletal changes in inflammatory arthritis:bone biomarkers. Curr Opin Rheumatol, 16:428-34.

Garnero P, Ferreras M, Karsdal MA, et al. 2003. The type I collagen fragments ICTP and CTX reveal distinct enzymatic pathways of bone collagen degradation. J Bone Miner Res, 18:859-67.

Garnero P, Jouvenne P, Buchs N, et al. 1999. Uncoupling of bone metabolism in rheumatoid arthritis patients with or without joint destruction: assessment with serum type I collagen breakdown products. Bone, 24:381-5.

Genant HK, Engelke K, Fuerst T, et al. 1996. Noninvasive assessment of bone mineral and structure:state of the art. J Bone Miner Res, 11:707-30.

Genovese MC, Bathon JM, Martin RW, et al. 2002. Etanercept versus methotrexate in patients with early rheumatoid arthritis:two-year radiographic and clinical outcomes. Arthritis Rheum, 46:1443-50.

Gilbert L, He X, Farmer P, et al. 2000. Inhibition of osteoblast differentiation by tumor necrosis factor - alpha. Endocrinology, 141:3956-64.

Gilbert L, He X, Farmer P, et al. 2002. Expression of the osteoblast differentiation factor RUNX2 (Cbfa1/AML3/Pebp2alpha A) is inhibited by tumor necrosis factor-alpha. $J$ Biol Chem, 277:2695-701.

Goldring SR, Gravallese EM. 2000. Mechanisms of bone loss in inflammatory arthritis:diagnosis and therapeutic implications. Arthritis Res, 2:33-7.

Gough AK, Lilley J, Eyre S, et al. 1994. Generalised bone loss in patients with early rheumatoid arthritis. Lancet, 344:23-7.

Gravallese EM. 2002. Bone destruction in arthritis. Ann Rheum Dis, 61(Suppl 2):ii84-6.

Gravallese EM, Harada Y, Wang JT, et al. 1998. Identification of cell types responsible for bone resorption in rheumatoid arthritis and juvenile rheumatoid arthritis. Am J Pathol, 152:943-51.

Gravallese EM, Manning C, Tsay A, et al. 2000. Synovial tissue in rheumatoid arthritis is a source of osteoclast differentiation factor. Arthritis Rheum, 43:250-8.

Green MJ, Deodhar AA. 2001. Bone changes in early rheumatoid arthritis. Best Pract Res Clin Rheumatol, 15:105-23.

Guler-Yuksel M, Bijsterbosch J, Goekoop-Ruiterman YP, et al. 2007. Changes in bone mineral density in patients with recent onset, active rheumatoid arthritis. Ann Rheum Dis, 67:823-8.

Hall GM, Spector TD, Griffin AJ, et al. 1993. The effect of rheumatoid arthritis and steroid therapy on bone density in postmenopausal women. Arthritis Rheum, 36:1510-6.

Haugeberg G, Orstavik RE, Uhlig T, et al. 2002. Bone loss in patients with rheumatoid arthritis:results from a population-based cohort of 366 patients followed up for two years. Arthritis Rheum, 46:1720-8.

Hill PA, Tumber A, Meikle MC. 1997. Multiple extracellular signals promote osteoblast survival and apoptosis. Endocrinology, 138:3849-58.
Hofbauer LC, Dunstan CR, Spelsberg TC, et al. 1998. Osteoprotegerin production by human osteoblast lineage cells is stimulated by vitamin $\mathrm{D}$, bone morphogenetic protein-2, and cytokines. Biochem Biophys Res Commun, 250:776-81.

Hofbauer LC, Heufelder AE. 2001. The role of osteoprotegerin and receptor activator of nuclear factor kappaB ligand in the pathogenesis and treatment of rheumatoid arthritis. Arthritis Rheum, 44:253-9.

Hoshino K, Hanyu T, Arai K, et al. 2001. Mineral density and histomorphometric assessment of bone changes in the proximal tibia early after induction of type II collagen-induced arthritis in growing and mature rats. J Bone Miner Metab, 19:76-83.

Huusko TM, Korpela M, Karppi P, et al. 2001. Threefold increased risk of hip fractures with rheumatoid arthritis in Central Finland. Ann Rheum Dis, 60:521-2.

Inui T, Ishibashi O, Inaoka T, et al. 1997. Cathepsin K antisense oligodeoxynucleotide inhibits osteoclastic bone resorption. $J$ Biol Chem, 272:8109-12.

Ishikawa H, Ohno O, Hirohata K. 1984. An electron microscopic study of the synovial-bone junction in rheumatoid arthritis. Rheumatol Int, 4:1-8.

Jensen T, Klarlund M, Hansen M, et al. 2004. Bone loss in unclassified polyarthritis and early rheumatoid arthritis is better detected by digital $\mathrm{x}$ ray radiogrammetry than dual $\mathrm{x}$ ray absorptiometry:relationship with disease activity and radiographic outcome. Ann Rheum Dis, 63:15-22.

Jilka RL, Weinstein RS, Bellido T, et al. 1998. Osteoblast programmed cell death (apoptosis):modulation by growth factors and cytokines. $J$ Bone Miner Res, 13:793-802.

Joosten LA, Helsen MM, Saxne T, et al. 1999. IL-1 alpha beta blockade prevents cartilage and bone destruction in murine type II collageninduced arthritis, whereas TNF-alpha blockade only ameliorates joint inflammation. J Immunol, 163:5049-55.

Kanematsu M, Sato T, Takai H, et al. 2000. Prostaglandin E2 induces expression of receptor activator of nuclear factor-kappa B ligand/osteoprotegrin ligand on pre-B cells:implications for accelerated osteoclastogenesis in estrogen deficiency. J Bone Miner Res, 15:1321-9.

Keystone EC, Kavanaugh AF, Sharp JT, et al. 2004. Radiographic, clinical, and functional outcomes of treatment with adalimumab (a human anti-tumor necrosis factor monoclonal antibody) in patients with active rheumatoid arthritis receiving concomitant methotrexate therapy: a randomized, placebo-controlled, 52-week trial. Arthritis Rheum, 50:1400-11.

Kong YY, Boyle WJ, Penninger JM. 2000. Osteoprotegerin ligand:a regulator of immune responses and bone physiology. Immunol Today, 21:495-502.

Kong YY, Feige U, Sarosi I, et al. 1999. Activated T cells regulate bone loss and joint destruction in adjuvant arthritis through osteoprotegerin ligand. Nature, 402:304-9.

Kroot EJ, Nieuwenhuizen MG, De Waal Malefijt, MC, et al. 2001. Change in bone mineral density in patients with rheumatoid arthritis during the first decade of the disease. Arthritis Rheum, 44:1254-60.

Kuroki T, Shingu M, Koshihara Y, et al. 1994. Effects of cytokines on alkaline phosphatase and osteocalcin production, calcification and calcium release by human osteoblastic cells. Br J Rheumatol, 33:224-30.

Laan RF, Buijs WC, Verbeek AL, et al. 1993. Bone mineral density in patients with recent onset rheumatoid arthritis:influence of disease activity and functional capacity. Ann Rheum Dis, 52:21-6.

Lange U, Teichmann J, Muller-Ladner U, et al. 2005. Increase in bone mineral density of patients with rheumatoid arthritis treated with antiTNF-alpha antibody:a prospective open-label pilot study. Rheumatology (Oxford), 44:1546-8.

Lipsky PE, Van Der Heijde DM, St Clair EW, et al. 2000. Infliximab and methotrexate in the treatment of rheumatoid arthritis. Anti-Tumor Necrosis Factor Trial in Rheumatoid Arthritis with Concomitant Therapy Study Group. $N$ Engl J Med, 343:1594-602.

Maini R, St Clair EW, Breedveld F, et al. 1999. Infliximab (chimeric antitumour necrosis factor alpha monoclonal antibody) versus placebo in rheumatoid arthritis patients receiving concomitant methotrexate:a randomised phase III trial. ATTRACT Study Group. Lancet, 354:1932-9. 
Marotte H, Maslinski W, Miossec P. 2005. Circulating tumour necrosis factor-alpha bioactivity in rheumatoid arthritis patients treated with infliximab:link to clinical response. Arthritis Res Ther, 7:R149-55.

Marotte H, Pallot-Prades B, Grange L, et al. 2007. A 1-year case-control study in patients with rheumatoid arthritis indicates prevention of loss of bone mineral density in both responders and nonresponders to infliximab. Arthritis Res Ther, 9:R61.

McClung MR, Lewiecki EM, Cohen SB, et al. 2006. Denosumab in postmenopausal women with low bone mineral density. $N$ Engl $J$ Med 354:821-31.

Mikuls TR. 2003. Co-morbidity in rheumatoid arthritis. Best Pract Res Clin Rheumatol, 17:729-52.

Min H, Morony S, Sarosi I, et al. 2000. Osteoprotegerin reverses osteoporosis by inhibiting endosteal osteoclasts and prevents vascular calcification by blocking a process resembling osteoclastogenesis. $J$ Exp Med, 192:463-74.

Morony S, Capparelli C, Lee R, et al. 1999. A chimeric form of osteoprotegerin inhibits hypercalcemia and bone resorption induced by IL-1beta, TNF-alpha, PTH, PTHrP, and 1, 25(OH)2D3. J Bone Miner Res, 14:1478-85.

Nakase T, Takaoka K, Masuhara K, et al. 1997. Interleukin-1 beta enhances and tumor necrosis factor-alpha inhibits bone morphogenetic protein2-induced alkaline phosphatase activity in MC3T3-E1 osteoblastic cells. Bone, 21:17-21.

Nakashima T, Kobayashi Y, Yamasaki S, et al. 2000. Protein expression and functional difference of membrane-bound and soluble receptor activator of NF-kappaB ligand:modulation of the expression by osteotropic factors and cytokines. Biochem Biophys Res Commun, 275:768-75.

Nguyen L, Dewhirst FE, Hauschka PV, et al. 1991. Interleukin-1 beta stimulates bone resorption and inhibits bone formation in vivo. Lymphokine Cytokine Res, 10:15-21.

Pacifici R, Avioli LV. 1993. The effect of natural and surgical menopause on the secretion of cytokines from human blood monocytes. Osteoporos Int, 3(Suppl 1):106-7.

Page G, Miossec, P. 2005. RANK and RANKL expression as markers of dendritic cell-T cell interactions in paired samples of rheumatoid synovium and lymph nodes. Arthritis Rheum, 52:2307-12.

Peel NF, Moore DJ, Barrington NA, et al. 1995. Risk of vertebral fracture and relationship to bone mineral density in steroid treated rheumatoid arthritis. Ann Rheum Dis, 54:801-6.

Pettit AR, Ji H, Von Stechow D, et al. 2001. TRANCE/RANKL knockout mice are protected from bone erosion in a serum transfer model of arthritis. Am J Pathol, 159:1689-99.

Redlich K, Hayer S, Maier A, et al. 2002a. Tumor necrosis factor alphamediated joint destruction is inhibited by targeting osteoclasts with osteoprotegerin. Arthritis Rheum, 46:785-92.

Redlich K, Hayer S, Ricci R, et al. 2002b. Osteoclasts are essential for TNFalpha-mediated joint destruction. J Clin Invest, 110:1419-27.

Ritchlin CT, Haas-Smith SA, Li P, et al. 2003. Mechanisms of TNF-alphaand RANKL-mediated osteoclastogenesis and bone resorption in psoriatic arthritis. J Clin Invest, 111:821-31.

Romas E, Sims NA, Hards DK, et al. 2002. Osteoprotegerin reduces osteoclast numbers and prevents bone erosion in collagen-induced arthritis Am J Pathol, 161:1419-27.

Saidenberg-Kermanac'H N, Corrado A, Lemeiter D, et al. 2004. TNF-alpha antibodies and osteoprotegerin decrease systemic bone loss associated with inflammation through distinct mechanisms in collagen-induced arthritis. Bone, 35:1200-7.

Sambrook PN, Eisman JA, Champion GD, et al. 1987. Determinants of axial bone loss in rheumatoid arthritis. Arthritis Rheum, 30:721-8.

Sassi ML, Eriksen H, Risteli L, et al. 2000. Immunochemical characterization of assay for carboxyterminal telopeptide of human type I collagen: loss of antigenicity by treatment with cathepsin K. Bone, 26:367-73.
Seriolo B, Ferretti V, Sulli A, et al. 2002. Serum osteocalcin levels in premenopausal rheumatoid arthritis patients. Ann N Y Acad Sci, 966:502-7.

Shenstone BD, Mahmoud A, Woodward R, et al. 1994. Longitudinal bone mineral density changes in early rheumatoid arthritis. Br J Rheumatol, 33:541-5.

Shigeyama Y, Pap T, Kunzler P, et al. 2000. Expression of osteoclast differentiation factor in rheumatoid arthritis. Arthritis Rheum, 43:2523-30.

Smolen JS, Han C, Bala M, et al. 2005. Evidence of radiographic benefit of treatment with infliximab plus methotrexate in rheumatoid arthritis patients who had no clinical improvement:a detailed subanalysis of data from the anti-tumor necrosis factor trial in rheumatoid arthritis with concomitant therapy study. Arthritis Rheum, 52:1020-30.

Spector TD, Hall GM, McCloskey EV, et al. 1993. Risk of vertebral fracture in women with rheumatoid arthritis. BMJ, 306:558.

Taichman RS, Hauschka PV. 1992. Effects of interleukin-1 beta and tumor necrosis factor-alpha on osteoblastic expression of osteocalcin and mineralized extracellular matrix in vitro. Inflammation, 16:587-601.

Takayanagi H, Iizuka H, Juji T, et al. 2000. Involvement of receptor activator of nuclear factor kappaB ligand/osteoclast differentiation factor in osteoclastogenesis from synoviocytes in rheumatoid arthritis. Arthritis Rheum, 43:259-69.

Torikai E, Kageyama Y, Takahashi M, et al. 2006. The effect of infliximab on bone metabolism markers in patients with rheumatoid arthritis. Rheumatology (Oxford), 45:761-4.

Van Staa TP, Geusens P, Bijlsma JW, et al. 2006. Clinical assessment of the long-term risk of fracture in patients with rheumatoid arthritis. Arthritis Rheum, 54:3104-12.

Vergely N, Lafage-Proust MH, Caillot-Augusseau A, et al. 2002. Hypercorticism blunts circadian variations of osteocalcin regardless of nutritional status. Bone, 30:428-35.

Vis M, Havaardsholm EA, Haugeberg G, et al. 2006. Evaluation of bone mineral density, bone metabolism, osteoprotegerin and receptor activator of the NFkappaB ligand serum levels during treatment with infliximab in patients with rheumatoid arthritis. Ann Rheum Dis, 65:1495-9.

Vis M, Voskuyl AE, Wolbink GJ, et al. 2005. Bone mineral density in patients with rheumatoid arthritis treated with infliximab. Ann Rheum Dis, 64:336-7.

Vis M, Wolbink GJ, Lodder MC, et al. 2003. Early changes in bone metabolism in rheumatoid arthritis patients treated with infliximab. Arthritis Rheum, 48:2996-7.

Warzocha K, Ribeiro P, Bienvenu J, et al. 1998. Genetic polymorphisms in the tumor necrosis factor locus influence non-Hodgkin's lymphoma outcome. Blood, 91:3574-81.

Weinblatt ME, Kremer JM, Bankhurst AD, et al. 1999. A trial of etanercept, a recombinant tumor necrosis factor receptor:Fc fusion protein, in patients with rheumatoid arthritis receiving methotrexate. $N$ Engl $J$ Med, 340:253-9.

Westhovens R, Dequeker J. 2000. Rheumatoid arthritis and osteoporosis. Z Rheumatol, 59(Suppl 1):33-8.

Yudoh K, Matsuno H, Osada R, et al. 2000. Decreased cellular activity and replicative capacity of osteoblastic cells isolated from the periarticular bone of rheumatoid arthritis patients compared with osteoarthritis patients. Arthritis Rheum, 43:2178-88.

Ziolkowska M, Kurowska M, Radzikowska A, et al. 2002. High levels of osteoprotegerin and soluble receptor activator of nuclear factor kappa B ligand in serum of rheumatoid arthritis patients and their normalization after anti-tumor necrosis factor alpha treatment. Arthritis Rheum, $46: 1744-53$ 
